\title{
Schizothorax richardsonii dsRNA dependent protein kinase has three double-stranded RNA binding motifs with a promoter lacking conserved kinase sequence
}

\section{Ankur Saxena}

Directorate of Coldwater Fisheries Research

\section{Kiran Belwal}

Directorate of Coldwater Fisheries Research

\section{Preeti Chaturvedi}

ICAR -Directorate of Coldwater Fisheries Research Bhimtal

Amit Pande ( $\nabla$ amit.pande@icar.gov.in )

Directorate of Coldwater Fisheries Research https://orcid.org/0000-0001-6794-2471

\section{Research article}

Keywords: chizothorax richardsonii , Interferon Stimulated Genes, PKR protein, Antiviral state, Homology modeling, dsRNA binding protein kinase

Posted Date: June 18th, 2020

DOI: https://doi.org/10.21203/rs.2.17575/v2

License: (c) (1) This work is licensed under a Creative Commons Attribution 4.0 International License.

Read Full License 
The authors have withdrawn this preprint from Research Square 